\title{
Social Change and Teaching and Learning Citizenship Education: An Empirical Study of Three Schools in Guangzhou, China
}

Citation: Law, W.-W., \& Xu, S. (2017). Social Change and Teaching and Learning Citizenship Education: An Empirical Study of Three Schools in Guangzhou, China. Citizenship Teaching and Learning, 12(1), 7-41.

\begin{abstract}
Since the 1980s, China has increased its openness to the world and made tremendous domestic economic and social changes. This study investigates the relationship between social change and pedagogies in citizenship education (CE) and to what extent indoctrination is prevalent in $\mathrm{CE}$ in schools in Guangzhou, China. Data were drawn mainly from documents, student questionnaires, observed CE lessons, and interviews with students and CE teachers. Findings revealed the coexistence of various $\mathrm{CE}$ pedagogies (e.g., inculcation; values clarification; inquiry-based); perceived open and free classrooms in which students expressed and respected diverse views; rote learning for examination, not political, purposes; and teachers' tension between reluctantly teaching politically-sensitive topics and promoting multiple perspectives to foster critical thinking. These findings may reflect the complex interplay among different actors in the reselection of CE elements and pedagogies, in response to China's gradual, post1980s social transition to a less restrictive, more accommodating society.
\end{abstract}

Keywords: Citizenship education, pedagogies, social change, China

\section{Introduction}

Numerous studies have stereotypically portrayed Asian (including Chinese) and Western classrooms as pedagogical opposites - teacher domination/rote learning vs. learner-centric, inquiry-based approaches, respectively (Grossman, 2010). Numerous studies have examined various values education (including citizenship education, CE) pedagogies, but few have addressed the relationships between CE pedagogies and social change. Several studies have asserted that, despite China's post-1980s education and curriculum reforms, indoctrination prevails in Chinese CE. This article seeks empirical evidence of such prevalence and explores whether the increased openness and diversity in Chinese society facilitates a more studentcentric, inquiry-based pedagogy.

The study challenges extant studies by partially debunking certain preconceptions concerning the prevalence of indoctrination in Chinese CE. Specifically, it argues that teaching/learning in Chinese $\mathrm{CE}$ is not static and isolated, but dynamic and influenced by societal and global change. It is a socio-political exercise and practice equipping students to become active, responsible citizens, involving the complex interplay among stakeholders and changing social contexts. In response to global/domestic social changes, Chinese CE has become less ideological and political, and more relevant to students' lives; its pedagogy has begun to shift from teacher- and textbook-centric rote learning, to student-centric, inquirybased learning. While not yet fully realized, this pedagogical paradigm shift reflects the new, state-initiated context of China's post-1980s reform and opening, the mediation of textbook content between national aspirations and educational needs, and the support of teachers and students. Data were drawn mainly from documents (including curriculum standards and 
textbooks), 15 observed lessons on Ideology and Moral Character, questionnaires completed by nearly 800 Grade 7-9 students, and interviews with 12 teachers and 32 students from three Guangzhou secondary schools in 2013-14.

The article first sets a theoretical framework for analyzing Chinese CE by reviewing approaches to teaching/learning $\mathrm{CE}$ and studies on Chinese $\mathrm{CE}$, before introducing the study's research design. Next, it presents survey findings on $\mathrm{CE}$ teaching/learning patterns, then suggests explanations for these, based on textbook analysis, observed lessons and interview data. Finally, it highlights theoretical implications for understanding teaching/learning $\mathrm{CE}$ in China's changing society.

\section{Approaches to Teaching/Learning CE}

$\mathrm{CE}$ is an important values education component (Taylor, 1994) that prepares students to become members of particular political/social orders (Biesta, 2009). It aims to equip students with the civic/political "knowledge, skills and values needed to function effectively within" local, national, and global communities (Banks, 2008, p. 129). CE contents can be delivered in a dedicated, time-tabled subject (e.g., moral/citizenship education), integrated into other subjects (e.g., history), and/or promoted in cross-curricular or extracurricular activities (Schulz, Ainley, Fraillon, Kerr, \& Losito, 2010).

Since 2000, values education has received increased attention due to religion's waning moral influence on daily lives, fewer "shared values and allegiance to the state" in multicultural societies, and declining community involvement in modern societies (Jordan, Carlile, \& Stack, 2008, p. 149). Values education pedagogies vary in their theoretical assumptions and underpinnings (Brady, 2010), and can be arrayed using a teacher/student role spectrum (Superka, Johnson, Hedstrom, Ford, \& Ahrens, 1976).

At the spectrum's teacher-centric end lies inculcation - direct instruction designed to shape students' dispositions and behaviors (Halstead \& Taylor, 2000) and instill specific prescribed/predetermined values in students (Jordan et al., 2008) - e.g., character education in the US and Britain (Arthur, 2005; Lickona, Eric, \& Lewis, 2003).

An extreme form of inculcation is indoctrination, which infringes on leaners' autonomy to exploit their credulity. Indoctrination is often deemed brainwashing, and inimical to openmindedness and toleration (Merry, 2005). Young (1997) called indoctrination the transmission of knowledge, theories, concepts, beliefs, values, or attitudes to learners whereby their "rational autonomy" is infringed upon and they uncritically accept what teachers teach (p. 499). Merry (2005) defined indoctrination as "a process of knowledge or belief transmission" that cripples learners' "reflective capacities with respect to particular content" and prevents critical thinking (p. 406). Merry further provided four useful criteria for indoctrination: the intention to exert psychological control to discourage critical reflection and thinking; teaching content that is unsupported by evidence and may reasonably be disputed; coercive teaching strategies "that circumvent reasons and exert psychological pressure"; and, teaching outcomes that uncritically uphold specific convictions, despite counterevidence (pp. 407, 408). Although Kohlberg (1978) argued indoctrination in moral education need not compromise children's rights and free will, this prescriptive approach has been criticized for undermining students' active role in understanding and choosing their values (Curriculum Corporation, 2003).

At the spectrum's learner-centric end lie values clarification (VC) and cognitivedevelopment approaches, which emphasize teachers' role as facilitators, and discourage imposing prescribed values. VC encourages a prescribed values development process (awareness, clarification, affirmation, selection, action) incorporating teacher questioning, small-group discussion, simulations and role play (Brady, 2011; Raths, Harmin, \& Simon, 1966). Teachers withhold their views, positions and judgments to avoid influencing students, 
and facilitate and respect students' values choices (Leming, 2010). Although not identical to enquiry- or inquiry-based approaches (Thelen, 1987), all three involve posing questions/problems and preparing situations (Dostal, 2015). Similar to inquiry learning, VC can encourage teachers to motivate students' learning by posing questions, making hypotheses, collecting/analyzing data, and drawing conclusions (Tudball, 2007). Similarly, a cognitivedevelopment approach emphasizes facilitating students' reasoning, active thinking, and judgement when choosing values, and assessing the benefits/consequences of moral/social issues before acting (Brady, 2011). However, VC is criticized for undermining the role of authorities, parents and community (Leming, 2010), and cognitive-development approaches for neglecting students' emotional responses and behavioral changes (Curriculum Corporation, 2003).

Between these extremes lie discussion-based approaches, which are "more experiential and less didactic" (Halstead \& Taylor, 2000, p. 181), and action learning, which emphasizes students' valuing, freely choosing, and acting on values (Huitt, 2004; Superka et al., 1976). Both are criticized for overestimating students" ability to "manage productive dilemma discussions," and for teachers" "lack of salience" in students' growth (Leming, 2010, p. 99).

CE pedagogy has received less specific research attention than values education. Though numerous studies (e.g., Arthur \& Cremin, 2012; Arthur, Davies, \& Hahn, 2008; Banks, 2009) have addressed CE's ideas, perspectives, curriculum, and responses to such issues as globalization, less attention has been paid to its pedagogy. The 1999 IEA Civic Education Project (CEP), a pioneering, large-scale study of CE teaching/learning, reported teacher-centric methods and textbook reliance were prevalent in 28 participating societies (Losito \& Mintrop, 2001). The project also explored whether CE students could challenge their teachers on political/social issues, and whether their views were respected (Torney-Purta, Lehmann, Oswald, \& Schulz, 2001). China did not participate in this project.

Kennedy, Lee and Grossman (2010) showed diverse, still-developing CE pedagogies in 13 Asia-Pacific societies, including China. Grossman (2010) debunked stereotypes contrasting Asian (teacher-centric, rote learning) and Western (learner-centric, inquiry-based) pedagogies, while Lee (2010) argued both societies combined nation-oriented ("nationalistic, ideological, inculcating, expository, content-based, examination-based, and conservative"), person-oriented (experiential, reflective, affective, relevant to individuals' daily life and citizenship needs), and global-oriented (democracy, critical thinking, universal/international practices) pedagogies, to different extents (p. 354). This trichotomy is potentially misleading, as most CE curricula are multidimensional, rarely focusing on a single domain (Law, 2004). Moreover, pedagogies are not mutually exclusive and teaching/learning elements can be shared across domains; e.g., nation-specific elements can be inculcating or experiential and affective, and can involve critical thinking.

An important $\mathrm{CE}$ issue concerns whether and how to teach political issues, especially controversial or socially-divisive ones (Holden, 2002). Gutman (1999) contended schools have greater capacity than parents and other institutions to teach students to rationally assess competing political concepts. There are four major approaches to teaching political issues: avoidance (shunning political issues); denial (deeming an issue apolitical and answerable, and guiding students to answer it); privilege (teaching from a particular political perspective); and balance (presenting a "fair hearing" of varied views) (Hess, 2004, p. 259).

The balanced approach requires creating a "political classroom" in which competing political views are presented in a fair, reasonable manner (Hess \& McAvoy, 2015), and students are not unfairly influenced by teachers presenting conflicting views unequally (Huddleston, 2003). Student- or enquiry-based approach can be adopted; Northern Ireland schools used various teaching strategies (e.g., questioning, feedback) to stimulate students' critical thinking and engage them in exploring multiple perspectives, gathering, managing and processing 
information, critically examining evidence, and drawing conclusions (Council for the Curriculum Examinations and Assessment, 2014).

Unlike VC, the balanced and enquiry-based approaches position teachers as facilitators when teaching political issues; classrooms are "political" and "cannot be considered neutral" as they are "undergirded by values that promote a particular view" (e.g., of US democracy) (Hess \& McAvoy, 2015, p. 4). As facilitators, CE teachers need not remain neutral, and may stimulate student learning by, for example, reciting official views, playing devil's advocate, or declaring their own position (Council for the Curriculum Examinations and Assessment, 2014). However, how to introduce and teach political issues depends on the school's specific contexts (Graff, 2000).

Although CE is compulsory for students at all educational levels, there are few studies on pedagogy and learners' role in Chinese CE (Lee \& Ho, 2008). In the 2000s and early 2010s, CE curriculum standards were significantly revised to reflect China's effort to shift to studentcentric, inquiry-based pedagogy.

Many studies (e.g., Chen \& Reid, 2002; Lee, 1996; Lee \& Ho, 2008) showed that, while still emphasizing patriotism, collectivism and the leadership of Communist Party of China (CPC), since the 1978 Open Door reforms China has gradually reduced CE's political/ideological content and broadened its focus to include children's personal growth; their family, community, national and global roles; family, social and vocational ethics; and global awareness. Law (2011) and Wang and Tan (2014) showed that Chinese CE's ideological dualism (capitalism versus communism) has been gradually replaced by a more accommodative multidimensional framework centered on students' community spheres (family, school, local, national and international). Others (e.g., Fairbrother, 2003; Pan, 2011) demonstrated the revised CE's influences on students at all levels, while Kennedy, Fairbrother and Zhao (2014) examined how China recaptured some issues to prepare its citizenry for the $21^{\text {st }}$ century.

The few studies examining Chinese CE pedagogy agree that Chinese schools, primary to post-secondary, indoctrinate students with political views and nationalistic ideals. Li (1990) regarded China's 1980s' CE as specifically designed for political indoctrination, a view echoed by Xie and Li (2010). Surveying nearly 2,000 Peking University students, Cantoni et al (2014) contended that China's senior secondary school curriculum (revised in the 2000s) had "effectively indoctrinate[d]" them to see Chinese political institutions as democratic, free markets as limited, and state intervention in the market economy as acceptable (p. 30). Shen (2009) used the Chinese term guanshu (translated as "indoctrination") to stress the importance of using a soft-sell approach to political and ideological education, to "indoctrinate" students to "unconsciously identify with and accept" (buzhi bujue zhong renke bing jieshou) the values they are taught (p. 138). Although Zhao and Fairbrother (2010) commented that "explicit indoctrination of political propaganda [is] commonly practised in Chinese schools," they found some Chinese schools and scholars piloted more open and student-centric pedagogies (p. 42). Except for Shen (2009), these studies on Chinese CE use the terms "indoctrination" or "indoctrinate" loosely, and (unlike Merry (2005)) have no clear criteria for indoctrination upon which they base their observations and comments.

The general literature on values education pedagogies and teaching political issues offers a useful theoretical framework for examining the pedagogies used in Chinese CE, and for designing this study's student survey and student/teacher interviews. In particular, Merry's (2005) four indoctrination criteria guide the analysis and discussion of this study's findings, and inform whether indoctrination is used in Chinese CE curriculum and lessons. Specific studies on Chinese $\mathrm{CE}$ and its pedagogies illuminate the development, policy, teaching/learning of Chinese $\mathrm{CE}$, but have not investigated actual Chinese $\mathrm{CE}$ lessons, lack strong, classroom-level empirical evidence of indoctrination, and are insufficient to explain 
five major aspects of Chinese CE classrooms: the coexistence of diverse pedagogies; the struggle between teacher authority and student autonomy; students' active rational approach to learning CE; the free and open class climate felt by students; and variations in students' gradespecific CE learning requirements.

\section{The Research Study}

\section{Background}

The CPC still monopolizes Chinese politics and leadership, socialism remains China's governing ideology, and citizens' social and online interactions are tightly controlled, particularly regarding politically-sensitive events, or topics that threaten CPC leadership or social stability - e.g., Tibetan independence (Law, 2011). In 2013-14, the CPC tightened its political/social control of the public sphere: arresting activists; reminding universities not to teach human rights, universal values, freedom of speech and civil society; removing crosses from churches in Zhejiang Province; and, in 2016, demanding the mass media support the CPC's party line and positions.

In some ways, however, China has made tremendous economic and social changes, and Chinese society has become more accommodative. Since the 1978 Open Door policy, China's economy and society have become more open to outside participation (including by Western countries). The economy has enlarged to include private sector and market forces; middle and upper classes have emerged, and civil society grown; traditional and new media have bloomed and compete for audiences; the Internet and Internet-connected devices facilitate communication and access to information; and people have access to more diverse opportunities, including overseas study, travel and shopping (Law, 2011). This has exposed the Chinese people to diverse societies, information and knowledge, domestic and foreign, and lessened restrictions on freedoms of expression, speech, and assembly, both in society and cyberspace. Citizens commonly use the Internet and social media to criticize public policies and express dissatisfaction with government performance. Pubic protest is a "daily phenomenon" (Tanner, 2015), and Chinese authorities informally tolerate, even encourage, small-scale protests (Lorentzen, 2013).

This study does not claim China is as open and pluralistic as the US or Britain; merely that it is more open and accommodating now than it was from 1950-1980. The impact of President Xi's tightening of social and political control since 2013 on CE pedagogies will take time to emerge; this study explored the impact of pre-2013 social changes.

\section{Research Methods}

This study investigates the influences of social change on CE pedagogies and seeks classroomlevel evidence regarding the prevalence of indoctrination as a pedagogical approach. In China, $\mathrm{CE}$ is a mandatory subject at all grade levels, and is also promoted in other subjects (history, geography, etc.) and extracurricular activities (Ho, 2010; Jones, 2002). The study investigates students' perception of CE teaching/learning and explores class climate and teachers' and students' roles in Ideology and Moral Character, the Grades 7-9 version of CE. It poses four interrelated research questions.

(1) What major pedagogies are used by Chinese teachers in CE lessons?

(2) What are the major classroom-level teacher/student interactions in these lessons?

(3) Why and how do Chinese teachers encourage students to accept/reject the views/values they teach? 
(4) To what extent are Chinese students willing to share their views/values in class, and do they feel respected when doing so?

Although Beijing, Guangzhou and Shanghai - all important, globally-open cities actively involved in curriculum reforms - were all appropriate venues for this small-scale study, Guangzhou, a political, economic and cultural center in southern China, was selected.

Once China's sole official port of entry, Guangzhou has a centuries-long history of exposure to Western countries and ideas. The China Import and Export Fair (Canton Fair) attracts traders from around the world, and Guangzhou's citizens watch TV channels from Hong Kong, a highly-Westernized former British colony. Guangzhou was among the first cities to implement China's 2001 revised national school curriculum for secondary students, and to abandon "mechanical method of inculcation" in favor of students' willing participation in learning, and equitable teacher-student relationships (Guangzhou Education Bureau, 2002).

Similar to the 1999 CEP and 2009 International Civic and Citizenship Education Study, this study targeted junior secondary students (Grades 7-9). The researchers used personal connections to enlist three junior secondary public schools in Guangzhou in in-depth observation/analysis of CE lessons, something difficult for researchers from outside Mainland China to achieve. Schools A and B were administered by district education bureaus; School C was run by a state enterprise.

The study used three complementary data-collection methods: lesson observations, a student questionnaire, and interviews. First, the study observed $15 \mathrm{CE}$ (Ideology and Moral Character) lessons to capture complex teacher-student/student-student interactions: one for each grade in School A, and two for each grade in Schools B and C (Table 1). Classes were selected mainly to match CE lesson schedules and school visit days. An observation checklist captured teaching/learning activities, teacher's questions/feedbacks, and students' responses and participation. To minimize classroom teaching/learning interruptions, non-participant lesson observation (Jackson, 2011) was used. The average lesson length was 40 minutes. All lessons were video-recorded with permission and later transcribed for analysis.

\section{[Table 1 about here]}

Second, a questionnaire explored students' perceptions of teaching/learning in CE lessons through 72 items addressing: (1) teachers' major CE-promoting activities; (2) teachers' openness in teaching and relative emphasis of three CE domains (knowledge; skills; values and attitudes); (3) classroom climate; (4) teacher-student interactions; and, (5) students' valuelearning strategies. Questionnaire design was guided by extant values education pedagogy literature, and most questions were self-developed. Three questions concerning students' freedom and others' acceptance of their expressed views were adapted from the 1999 CEP (Torney-Purta et al., 2001); some questions on teacher-student interactions and classroom climate were based on Brown et al.'s (2001) exploration of effective teaching in mathematics.

After consulting a local $\mathrm{CE}$ expert and piloting the questionnaire among three Guangzhou junior secondary students, some questionnaire wordings were adjusted for clarity. Students used a four-point Likert scale to indicate their preferences ( $1=$ never/very infrequent to $4=$ very frequent in Part $1 ; 1=$ strongly disagree to $4=$ strongly agree in Parts $2-5$ ). Non-CE homeroom teachers distributed 820, and collected 787 questionnaires from 15 observed classes (96\% return rate); all returned questionnaires were useful. Forty-eight percent of respondents were male and 52\% female; $32 \%$ were in Grade 7, 31.5\% in Grade 8, and 36.5\% in Grade 9 (Table 1). The overall reliability of the questions was high (Cronbach's alpha=.970). 
Third, individual, post-observation, semi-structured student/teacher interviews were conducted to probe in-depth views on classroom CE. Teachers were asked about, for example, teaching activities and questions commonly used to guide students; students' responses thereto; teacher feedback; and, how they handled student-student/student-teacher differences of opinion. Students were asked about, for example, what teaching methods helped them explore moral, social, and political issues; their participation in class activities; and, their experiences with accepting/rejecting others' values/viewpoints. Twelve (four male, eight female) of the 15 observed teachers (one of whom taught three observed classes) were interviewed (Table 1). Their average years of teaching and of teaching CE were 18 and 15, respectively. Seven were specialist citizenship teachers who had received professional $\mathrm{CE}$ teaching training; the others were trained in other education-related disciplines. The study also conducted 16 (two individual, 12 two-person, and two three-person) interviews with 32 students (recommended by observed teachers). The average interview lasted 45 minutes for teachers, and 30 minutes for students. All interviews were audio-recorded and transcribed for analysis.

The quantitative and qualitative data were analyzed with Statistical Package for Social Sciences (SPSS) and NVivo software, respectively. Factor and cluster analyses identified patterns in findings, and t-test or ANOVA were used to determine the statistical significance of interrelationships. The study post-coded interview data and observed lesson contents, identified and clustered units of meaning relevant to the research questions, generated themes from the clusters, and compared these with patterns in the survey data. The observed lessons were further analyzed for the frequencies and timing of different teaching/learning activities (e.g., teacher talk, feedback to students, student answers, and small-group discussion).

This empirical study is not representative, and is limited in three major aspects: its small scale relative to the numbers of Chinese schools and areas; its focus on junior secondary education; and its snapshot representation of an extended curriculum reform process. Its findings are not generalizable to other schools in Guangzhou or elsewhere in China.

\section{Major Questionnaire Findings: Coexistence of Mixed CE Pedagogies in Chinese Schools}

This section reports five major, interrelated questionnaire findings on students' perceptions of $\mathrm{CE}$ teaching/learning that reveal the coexistence of mixed CE pedagogies in the three schools. The first four reflect patterns of teacher-student interactions, teacher/student roles, and classroom climate; the last shows statistically-different student responses between Grades. The survey found no statistically-significant gender differences in student responses.

The first pattern shows diverse CE teaching/learning activities, rather than the domination of inculcation (Pattern 1). Students reported their CE teachers went beyond direct instruction and included class activities that engaged them in learning and thinking (see Table 2, Part 1), including, teacher talks and instructs, individual seatwork, and questions-andanswer. Less frequent activities included teacher-assigned, small-group discussion, discussing teacher-provided, value-laden scenarios, debate, and role playing, drama or simulation games.

\section{[Table 2 about here]}

These activities emphasized teaching values and attitudes, knowledge, and skills (Table 2, Part 2). Paired-samples t-tests showed a statistically-significant preference for cultivating values and attitudes, rather than knowledge or skills; the difference in means between knowledge and skills was statistically insignificant.

The second pattern concerns teachers' tensions regarding their role in CE lessons (Pattern 2). Students perceived their teachers to be caught between hoping students accept the knowledge, attitudes, values, and skills they taught, and allowing students to express different 
views and make choices (Table 2, Part 2). In particular, students agreed teachers encouraged them to accept or reject certain views, values and attitudes, including those promoted/discouraged by the government, widely accepted/discouraged in society, or considered good/bad by teachers. Paired-samples t-tests revealed no statistically-significant differences in means among these three major sources of views, values and attitudes teachers encouraged students to accept or reject.

Students also agreed their CE teachers did not unilaterally impose views, values and attitudes on them, but used VC or cognitive-development approaches to help students express, explore and clarify their views - e.g., asking students to recall information presented/discussed in class, clarify their understanding, give simple answers (Table 2, Part 4), explore and evaluate alternative positions, and (despite having little opportunity for extended explanations) develop answers. Another strategy involved using simple/detailed feedback to help students clarify their understanding and further explain their choices.

Moreover, students indicated that CE teachers presented a values issue's pros, cons and alternatives for consideration, then explained their reasons for accepting/rejecting them. Paired-samples tests revealed students' statistically-significant preference for being presented pros and cons over alternatives, and for alternatives over teacher's acceptance/rejection rationale. Although $\mathrm{CE}$ teachers used authority to convince students, they also allowed students' choices, with the former having a statistically-significant higher importance.

The third pattern relates to students' role in CE lessons (Pattern 3) as active, rational learners who thought, reasoned, and used strategies to assess/choose values, rather than as passive receivers of $\mathrm{CE}$ teaching. First, students reported being generally active learning participants who interacted with teachers by asking/responding to questions, sharing values, attitudes or views not endorsed by government, society, teachers or classmates, and seeking clarification from teachers (Table 2, Part 5).

Second, students adopted four information processing and evaluating strategies for teachers' talk and classmates' small-group/whole-class sharing: listening carefully; comparing their beliefs/views to the speaker's; seeking clarification; and, analyzing the speaker's reasons.

Third, students' strategies and preference for sharing views in class depended on whose values they were and whether they shared them. When taught values, attitudes and views similar their own, students preferred those promoted by government, society, teacher, and most classmates, in that order. Students' willingness to express views they shared with government was statistically-significant; their willingness to express views shared with society, teachers, or classmates was not.

When students' values, attitudes or views differed from those taught, their preferred order of sharing was reversed - classmates, teacher, society, then government. Students were statistically-significantly more willing to share values, attitudes and views different from theirs if held by classmates or teachers, rather than by government or society.

The fourth pattern concerns classroom climate for CE learning (Pattern 4). Students generally agreed they learned $\mathrm{CE}$ in an open classroom climate, and could freely express their views. They felt free to express opinions different from their classmates' and teachers', believed their teachers cared about and helped them openly share their feelings and views (Table 2, Part 3).

ANOVA showed no statistically-significant differences in means between these response items. However, multiple regression analysis revealed they could be predictor variables of the response variable (open and free classroom climate full of trust, respect and acceptance), with moderate interactional influence on (or association to) classroom climate. The largest positive contributor to classroom climate was students' freedom to express views different from their teachers'; the least was teacher's concern for students' feelings. Students agreed their CE class featured respect, trust and acceptance (Table 2, Part 5), and generally felt 
respected, trusted, and accepted in their personal CE learning experiences. Students willingly shared in CE lessons, both in small-group discussions and when explaining themselves in response to teachers' questions. Seventy percent and 66.9\%, respectively, agreed they actively seized opportunities to share their views in class, and liked doing so. Paired-samples t-tests showed students felt freer to communicate their views in small-group discussions than at the class level, to a statistically significant degree.

The fifth pattern relates to grade-level student responses (Pattern 5). Grade 7 and 8 students showed no statistically-significant differences in most survey items (Table 2, Column

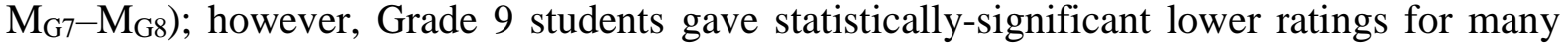
items in all parts of the questionnaire (Columns $\mathrm{M}_{\mathrm{G} 7}-\mathrm{M}_{\mathrm{G} 9}$ and $\mathrm{M}_{\mathrm{G} 8}-\mathrm{M}_{\mathrm{G} 9}$ ). First, Grade $9 \mathrm{CE}$ pedagogies were less diversified than those in Grades 7 and Eight, with statistical significance. Grade 9 students indicated having fewer opportunities for debate, role play and stimulation games, and discussing teacher-provided value-laden situations than their younger counterparts. Moreover, although teachers cultivated and cared about their CE knowledge, values, and skills, students statistically-significantly reported teachers emphasized values and skills less in Grade 9 than in earlier grades.

Second, despite being presented with pros, cons, and alternative views, and allowed to choose their values, students felt Grade 9 teachers emphasized these aspects less than did Grade 7 or 8 teachers, with statistical significance. Third, the perceived classroom climate in Grade 9 was less free and open, with students less inclined to ask or answer questions. Fourth, Grade 9 students were less active, with statistical significance, in sharing their views in small groups or at the class level. Fifth, Grade 9 students made less use of the four CE information processing and evaluating strategies.

\section{Discussion: Possible Explanations}

Based on interview data, analysis of curriculum standards and textbooks, and lesson observations, this section suggests possible explanations for the five CE teaching/learning patterns found in the sample schools. It argues these patterns can be interpreted as resulting from the intertwined influences of China's increasingly open and pluralistic societal context, stakeholders' (including government and teachers) efforts to introduce classroom-level student-centric, inquiry-based learning, and the lingering influence of China's examinationcentered education culture. This interplay means CE teaching/learning in the sample schools did not meet Merry's (2005) criteria for indoctrination, but was tilted more towards VC or cognitive development approaches (Leming, 2010). The long and short interview data and textbook quotations were translated by the authors from Chinese to English. Codes are used to identify school (Sch), teacher (T) and student (S), such that SchA-S3 refers to School A's third interviewed student.

\section{China's Increasingly Open, Less Restrictive Society under CPC Leadership}

Schools are not isolated from society and the world, and social context has long been an important factor affecting classroom teaching/learning (Tharp \& Gallimore, 1988). China is no exception. The first four patterns (diverse pedagogies, teacher tensions, students as rational learners, and learning climate openness) found in the three sample schools can be seen as reflecting China's increasingly open and more accommodating society, in which teachers and students are exposed to diverse information and views through various channels, making school-based indoctrination less easy.

China's increasing open and less restrictive society, identified earlier, refracts into and reflects from student learning, in and outside school. Students no longer rely solely on school 
and textbooks for information and knowledge, and can use TV, the Internet, and Internetconnected phones to access information and views unavailable at school - e.g., to access, in addition to traditional Chinese and Western music curriculum elements, Chinese and foreign popular music (Law \& Ho, 2015).

This study reveals that increased access to foreign and domestic information can open $\mathrm{CE}$ teaching to society and the world. In most observed lessons, CE teaching/learning contents were guided, but not limited, by state-prescribed curriculum and textbooks; however, over half of observed CE teachers used the Internet to find supplementary information about Guangzhou, China and other countries. In one Grade 8 CE lesson on Internet use, SchC-T2 invited students to comment on two downloaded news articles - a local story about a hospital patient, and an international story about US basketball.

Interviews revealed teachers mainly used supplementary materials to increase lessons' relevance to students' daily lives, motivate students to learn, and broaden students' horizons by encouraging them to access extracurricular knowledge and information, particularly online. Students (e.g., SchA-S1, SchB-S5, SchC-S9) indicated that watching local, national, and international TV news and documentaries, searching for information online, and reading others' views on the same issues posted on social media broadened their knowledge and stimulated their thinking. SchA-T3 claimed it was "impossible to impose" views/values on students, because they were prudent, and accessed diverse information and perspectives online.

\section{Curriculum Reform for Pedagogic Shifts in Teaching/Learning}

The first four patterns can partly be explained in terms of the post-2000 collective efforts of the Chinese government and frontline teachers to promote student-centric learning; in CE, this involved favoring $\mathrm{VC}$ and inquiry-based approach over indoctrination. To demonstrate this, the study compared CE teaching/learning in the sample schools - specifically, government-led reform of curriculum, pedagogy, and textbook contents - to Merry's (2005) criteria for indoctrination. It then investigated the methods proposed in textbooks and used by teachers in observed lessons, and whether students were forced to accept classroom teachings uncritically.

\section{National Aspirations for Pedagogical Changes Embedded in Curriculum Standards}

Since the 1978 Open Door policy, the Chinese government has made several nationwide school curriculum reforms to help students cope with domestic social changes and global challenges, and to enhance China's manpower quality and capacity for international competition (Law, 2014). To reduce barriers caused by traditional pedagogy and low educational quality, the Ministry of Education (MoE) proposed two related pedagogical changes - from teacher-centric to student-centric teaching, and from rote to inquiry-based learning (MoE, 2001a). The changes were not intended to discourage critical reflection and thinking (which Merry (2005) cites as an indoctrination criterion), but to equip students to become life-long learners able to acquire and process new knowledge, solve problems, and exercise independent thought (MoE, 2001a).

This was reflected and extended in the 2001 revised and 2011 fine-tuned school subject curriculum standards. Similar to English national citizenship programs, which prescribe specific knowledge and values (e.g., democracy, liberties and justice) for secondary students (Department for Education of the United Kingdom, 2013), the revised Chinese CE curriculum emphasizes loving socialism, patriotism, and collectivism. Nonetheless, the 2001 revised CE curriculum stressed developing students' independent thinking skills - in particular, mastering inquiry-based learning (MoE, 2001b) - similar to Northern Ireland's enquiry-based approach to teaching political issues (Council for the Curriculum Examinations and Assessment, 2014). The revised curriculum encouraged students to ask questions in Grades 1-2, actively seek 
answers in Grades 3-5, and explore and be creative in Grades 6-7; it also asked teachers to help students learn, express different views, and think from multiple perspectives (MoE, 2001b). The 2011 fine-tuned CE curriculum further reminded teachers that students' moral character development could not be "separated" (libukai) from their "independent thinking and active practice" (duli sikao he jiji shijian), and that students must exercise "independent thinking" to "genuinely accept" (zhenzheng jieshou) national/societal expectations (MoE, 2012a, p. 3).

Similarly, curriculum standards for non-CE subjects (e.g., Chinese language) stressed cultivating students' self-learning abilities, sense of curiosity and exploration, and desire for knowledge and innovation (MoE, 2001c). The 2011 Chinese language curriculum encouraged students to "express freely" and enhance their awareness by asking questions (Ministry of Education, 2012b).

This suggests Chinese authorities recognized indoctrination does not socialize students into CPC-prescribed values, and encouraged investigating from multiple perspectives and using inquiry-based learning to train students in independent thinking. In the mid-2010s, the MoE (2015) stipulated "active expression of opinions" as one of nine school mandatory behavior codes for primary and secondary students.

\section{Mediation of textbooks between Curriculum Standards and Classroom}

Despite criticizing textbook-centric pedagogy, Chinese authorities used textbooks as expanded curriculum standards to disseminate curricular and pedagogical changes among teachers and students, and, in the 2000s, gradually reformed CE textbooks to facilitate classroom-level changes (Wang \& Tan, 2014). The teaching contents and methods proposed in textbooks did not fit Merry's (2005) second and third criteria for indoctrination.

First, officially-approved junior secondary CE textbooks did not cover knowledge unsupported by available evidence. Grade 7-8 CE textbooks covered topics and issues relevant to students' life (e.g., self-awareness, relationships, life education, psychology, law), while the Grade 9 textbook focused on China's policies and political systems (Zhu, 2012); the relationships of self and nation to the world were subsumed into topics. The textbooks proposed issues/situations for teaching using real-life examples, and offered such answers as treasuring life and mastering one's emotions (Grade 7), loving and developing good interpersonal relationships (Grade 8), and accepting social responsibilities and contributing to society, China and the world (Grade 9). The only ideologically-loaded claim in the Grade 9 textbook concerned the "superiority" (youyuexing) of Chinese socialism (Curriculum and Teaching Materials Research Institute, 2011), which was not contrasted with capitalism (as in China's pre-1980s ideological propaganda), but supported by examples of China's post-1980s achievements. The claim is thus subjective, and reflects the CPC's use of CE textbooks to legitimize its leadership and development strategies (Vickers, 2009).

Second, CE textbooks promoted various pedagogies, including direct instruction and inquiry-based learning, by providing situations for student discussion and analysis, as in VC (Brady, 2011) or enquiry-based approaches (Council for the Curriculum Examinations and Assessment, 2014). For example, one Grade 8 unit's ("Competition and Cooperation for WinWin Situation") two sub-units ("Competition? Cooperation?" and "Cooperation! Competition!") presented nine competition-related situations for students to explore and discuss (Curriculum and Teaching Materials Research Institute, 2009), each with up to three questions. One scenario, involving two good friends competing in a high-level international sport, asked students about the implications of competition, whether competition necessarily hurt friendship, and how to compete without hurting friendships. Another situation encouraged students to cooperate while competing in a team-based simulated survival game (Mintz, 1951), suggest winning strategies, and reflect on what the game could teach them. 
However, the competition unit also directed students' study, by providing, after each situation, questions, key points and possible answers to ponder and memorize for examination, rather than political, purposes. After the simulated survival game, for example, the Grade 8 textbook highlighted the importance of cooperative competition as "a means to achieve a higher goal"; the importance of team spirit in cooperative competition; and the meaning of "win-win" (Curriculum and Teaching Materials Research Institute, 2009, p. 98).

\section{Evidence of Emerging Pedagogical Shifts at the Classroom Level}

The sample schools showed signs of China's two intended pedagogical shifts at the classroom level. Analysis of observed lessons revealed free and open class climates in which teachers used diverse strategies to engage students in inquiry-based learning, rather than dominating and spoon-feeding them. Teaching strategies were not coercive, and facilitated exploring, thinking, discussion and choice, consistent with student survey findings (q.v.). Thus, the observed lessons' climate and strategies did not fit Merry's (2005) third indoctrination criterion.

Diverse teaching activities and strategies were found in all observed lessons, including some similar to those in VC or cognitive-development approaches (Leming, 2010). Each observed lesson lasted 39 to 48 minutes, averaging 42 (Table 3). Teacher activities (e.g., task introductions, questioning, feedback to students) generally consumed $55 \%$ of class time (23 minutes); the student portion (19 minutes) included answering teacher questions, small-group discussion, individual seatwork, reading aloud and gameplay.

\section{[Table 3 about here]}

Although observed teaching/learning activities varied within and between schools (see Table 3), question-answer-feedback (25 minutes) was generally the most common teacherstudent interaction. Students more often raised questions, made suggestions, and discussed their views during small-group discussions (5 minutes) than during class-level sharing, often questioning teachers who came to check on the discussion.

The use of direct instruction and inquiry-based learning in various CE class activities can be illustrated using two observed Grade 8 lessons focused on competition and cooperation in school, society and the world, taught in School B by SchB-T3 and SchB-T4, using similar teaching strategies, for different lengths of time (Table 3). Initially, both teachers used direct instruction techniques - they wrote the same textbook passage's title and key points on the blackboard, asked empirical questions (e.g., What is the focus of today's lesson?) that generated rote responses, arranged activities to match the passage's key points, and made students play Mintz's survival game, before having them identify key terms and concepts.

However, SchB-T3 and SchB-T4 also acted as facilitators, by helping students explore the tension between competition and cooperation, and observed other elements of VC and inquiry-based learning (Brady, 2011). First, the observed lessons were teacher-guided, not teacher-dominated; question-answer-feedback was the major form of student-teacher interaction (23 minutes for SchB-T3, 22 for SchB-T4), followed by small-group discussion and group activities. Second, both teachers used scenarios to arouse student interest and thinking; interestingly, other than Mintz's survival game, they did not use textbook situations, but prepared their own based on School B's annual sporting event. SchB-T3 chose one prepared scenario for small-group discussion and SchB-T4 selected two; both invited students to share the results of their discussion in class.

Third, both teachers generated basic (mostly short) questions from the scenarios that were similar to those in the passage. They invited individual student responses, but accepted "collective" responses the class shouted together; in these observed lessons (as in others), 
students seldom raised questions at the class level. Fourth, both teachers used Mintz's survival simulation game (a VC tool (Brady, 2011)), to help students experience cooperative competition. They then guided students' post-game reflections on the game's lessons through class-level sharing and question-and-answer. SchB-T3 offered more feedback and follow-up questions than did SchB-T4; however, SchB-T4 better facilitated the simulation game by helping students evaluate whether competition or cooperation were more important in daily life, using in-depth questions and soliciting different groups' unique views.

\section{Teachers as Advocates for Diverse Pedagogies and Facilitators of Student Learning}

China's proposed pedagogical shifts and open teaching/learning climate cannot be realized in classrooms without teacher support. Students agreed CE teachers encouraged them to accept what was taught, but did not impose views on them. Unlike the "privilege" approach advocated for teaching political issues - i.e., by guiding students to accept a particular perspective (Hess, 2004) - all 12 interviewed teachers supported adopting a student-centric and inquiry-based pedagogy. Interview data showed teachers deemed themselves facilitators rather than spoonfeeders, and revealed their reasons for preferring diverse, inquiry-based teaching methods over indoctrination.

First, teachers held a low opinion of indoctrination and its coercive teaching strategies, criticizing it as an "ineffective means" of fostering young people's values and skills (SchBT2), "providing no space for students to talk freely and think independently" (SchB-T1), and not reflecting a "pluralistic society" (duoyuanhua shehui) in which people have "diverse needs" and make daily life choices (SchA-T2). SchB-T1, a respected specialist CE teacher and principal of School B, warned of the practical implications of indoctrination:

If teachers continue to use direct instruction and do not create space for students to express and provide them with multiple perspectives and options to choose, students would quit learning in CE lessons.

The teachers highly valued their role as facilitators, and engaged students in CE learning through diverse, inquiry-oriented teaching methods. Teachers described themselves as guides (rather than dominators), guiding students on "how to analyze an issue" (e.g., SchAT1 and SchC-T4) and "how to process and form value judgement" (e.g., SchB-T3 and SchC$\mathrm{T} 2$ ), rather than giving direct answers.

Teachers also supported using inquiry-based approaches to help students explore multiple perspectives of CE issues. Many (e.g., SchA-T2, SchB-T4 and SchC-T3) admitted not all CE issues are "black-and-white" or "right-or-wrong" and could have multiple answers involving diverse views/values. They agreed inquiry-based learning could help students explore, explain and defend their answers, and had pedagogical and practical advantages. The former included helping students explore, explain and defend their answers to teacher's questions (SchC-T1); providing diverse perspectives so students could consider more ideas, understand complex issues, and develop opinions through "examination and comparison" (SchB-T3); and enabling students "to choose and make sense of the values and attitudes they uphold" (SchA-T2). In practical terms, inquiry-based approaches "cultivate students" comparison and analysis capability" and help them on CE examinations, which require analyzing issues from multiple perspectives (SchA-T4).

The teachers realized the importance of using diverse strategies to engage students in inquiry-based CE learning, and regarded questioning as a major teacher-student interaction strategy. As SchC-T1 explained, questioning is a "practical and effective" method to "keep students focusing on what was taught" and change their learning mode "from passive listening 
to active thinking." Specifically, questioning can force students to reflect, explain and clarify issues and values in CE lessons:

Asking students to answer questions can keep them thinking by forcing them to explain their own viewpoints, and supplement and even challenge other students'. (SchB-T2)

Questioning provides opportunities for students to experience and reflect on different situations from different perspectives, and then clarify and decide what values and attitudes they should hold. (SchA-T3)

Teachers (e.g., SchA-T2, SchB-T4, and SchC-T3) saw small-group discussion as another major teaching strategy (albeit more student-student than teacher-student oriented), and used it to "enhance students' learning enthusiasm"; "increase students' participation in learning"; encourage students to "generate new ideas" and "share views in group"; "cultivate students' awareness of learning from one another" and "sense of appreciation of diverse views"; and provide opportunities for students to "compare others' views with theirs."

Teachers deemed good teacher-student relationships as important to sustaining a friendly CE learning atmosphere, and fostered them thusly. First, by sharing their life stories, successes and failures with students (e.g., SchB-T2's father's struggles to quit gambling), which "moved" or "motivated" some students (e.g., SchC-S7 and SchC-S8). Second, by positively reinforcing students by encouraging them to express their ideas, and showing appreciation and recognition for their achievements in or outside class.

No students were observed expressing radical views conflicting with those of the class or mainstream society. However, all teachers indicated they would normally allow students to finish such expressions, commend their courage, and invite them to elucidate. Some teachers (e.g., SchA-T1, SchB-T1 and SchC-T3) said they would correct student views that were "too radical," "conceptually wrong" or might negatively affect other students, by guiding them to compare their views with others' and explore the pros and cons of both. If students "insisted on their wrong views," they would invite them to discuss them after class.

\section{Students as Rational Learners}

China's shifts to student-centric pedagogy and inquiry-based learning is partly reflected in students' willingness to engage in thinking, express their views, and respect classmates' diverse views. In VC or enquiry-based approaches, students play an active role in processing information, evaluating views and making rational choices (Leming, 2010). The study found no evidence students were forced to uncritically accept knowledge contradicted by available evidence, Merry's (2005) fourth criterion for indoctrination. Rather, students were active, rational learners, and enjoyed the open climate in CE lessons (Patterns 3 and 4). Interview data show students recognized their roles in learning, and had different reasons and strategies for engaging in different learning activities, and coping with diverse views/values.

First, most students clearly distinguished their roles and responsibilities as learners, from teachers' as guides and instructors. Some students played dual roles - as learners guided by the teacher and other students, and as "teachers" guiding themselves and other students:

When I share my view as a response to my teacher's question in class, I am a "teacher" helping other classmates to learn and think too. After sharing, I sit down and listen to my teacher's feedback, which can make me and other classmates think further. (SchCS5, Grade 8) 
To some extent, we are both students and "teachers". Our teacher teaches and guides us, but when we discuss issues, we share our views with classmates and the teacher, and draw our own conclusions. (SchC-S3, Grade 7)

Second, students willingly engaged in question-and-answer activities, calling them a "natural and reasonable" type of teacher-student interaction (SchB-S2 and SchC-S12) and a way "to show cooperation with the teacher" (SchB-S3) and "to share and communicate ideas with classmates" (SchC-S8). Teacher's questions could also guide their thinking and help them consolidate and enrich their learning. For some students (e.g., SchB-S3 and SchC-S1), following the logic of teacher questions helped them "clarify" issues and think deeper. Question-and-answer activities allowed students to "self-check" whether they understood what had been taught and were thinking aright, enhanced their "self-esteem" and "self-pride" (SchBS1 and SchB-S7), and gained classmates" "respect" (SchC-S13). However, some were reluctant to share at the class level for fear of "providing wrong answers" (SchA-S3 and SchB-S10) and thus "losing face" (SchB-S8).

Students reported small-group discussion facilitated thinking better than question-andanswer, and was more comfortable and convenient for communicating their views at the class level - for eager and reluctant students both (including SchA-S3, SchB-S8 and SchB-S10). Students felt braver when speaking in small groups (SchA-S3 and SchC-S1), and had "more chances" to participate and "share ideas and viewpoints immediately" (SchB-S5 and SchCS9). Moreover, they felt "greater motivation" to "work harder" and "collaborate better" to get group honors during post-discussion whole-class sharing (SchC-S8). However, some found small group activities limiting; SchA-S6, for example, preferred direct instruction because it efficiently provided "right answers" for examinations.

Students' small-group learning strategies included sharing views for confirmation, listening to and comparing others' views, and choosing the better perspective:

In small-group discussion, we could find different views. ... I would share and explain my viewpoint. I would say whether I agree or disagree with other groupmates' viewpoints and give my explanation. (SchA-S4, Grade-9)

Group members could have different perspectives. We can discuss and analyze them, and decide which one is better. This is fun. (SchC-S7, Grade 8)

We can learn more about group members' views and discuss which one is better. (SchA-S2, Grade 8)

We can share and evaluate our views, discard those which are bad, keep those which are good, select the best one to represent the group's position, and present it to the class. (SchC-S9, Grade 8)

Students coped with views/values differing from theirs by listening to, appreciating and respecting them, noting that: each view has strengths and limitations; it is possible to have different perspectives on a single issue; and, different views stimulate thinking. They accepted different views as "not necessarily wrong" (SchA-S5), sought clarification and explanation from others (SchA-S2), discussed the differences with others after class (SchB-S3, SchB-S8), and explored the pros and cons of each view before choosing the better one (SchA-S4, SchBS3, SchB-S9, and SchC-S9).

Interviewed students had different considerations/strategies when sharing views/values that differed from teachers' and other classmates'; 75\% felt respected when doing so, in both 
small-group and whole-class activities. Common sharing strategies included explaining their views', and their similarities to and differences from others'. However, students generally showed more respect for authorities' views, were more willing to support similar views/values, and more reluctant to express contrary opinions, because authorities were "mostly correct," had "more knowledge" and "more experiences in life," and would "not intentionally teach students something wrong" (SchB-S7 and SchB-S8). Nonetheless, some students (e.g., SchBS3) would "not blindly accept" governments' or teachers' views/values; SchA-S5 noted that sometimes officials do not "see the reality and ask people for their opinions" before making policies. Students whose views differed from their teachers" would "quietly remind" teachers of this in class (e.g., SchC-S7), or discuss it with them after (e.g., SchC-S5).

In summary, since the 1980s, China's reforms have created a more open context for curriculum reform and CE teaching/learning, and a less restrictive class climate in which teachers can act as facilitators, and adopt student-centric, inquiry-based pedagogical approaches, and in which students have choices when exploring and discussing, and can become rational learners through their own judgement and CE learning strategies.

\section{Ideological and Practical Constraints on CE Teaching/Learning}

Despite pedagogical shifts towards inquiry-based learning, students still felt their teachers wanted them to accept what was taught (Pattern 2), and found the Grade 9 class climate less open and free (Pattern 5). Interview data suggests the space for CE teaching/learning, particularly in Grade 9, was constrained by politically-sensitive topics and practical concerns (e.g., examination pressure).

\section{Challenges of Politically Sensitive Topics to Teachers and Students}

Students indicated having less fun, and being less enthusiastic and free about sharing in Grade $9 \mathrm{CE}$, due to the different types and distribution of topics. Grade 7-8 curricula and textbooks focus mainly on knowledge and issues relevant to students' daily lives (Zhu, 2012); Grade 9 lessons emphasize China's politics and national policies, which are more esoteric, and ideological and politically sensitive.

The Grade 9 textbook's 28 sections contained scenarios and questions to spark students' discussion and thinking on three major types of topics. Seven sections addressed topics close to students' daily lives; e.g., being a wise consumer, examination pressure, future dreams. Nineteen sections covered topics less representative of students' daily lives, knowledge and experiences, such as contemporary social/cultural/economic developments to China's political, and China's economic and legal systems under CPC leadership. Two sections (the CPC's party line and primitive socialism) addressed more ideological and abstract issues that provided the ideological justification for continued CPC leadership, and were less open to debate. Some CE teachers criticized the Grade 9 textbook's emphasis on politics as "boring" (SchC-T3) and "too difficult" for students to grasp, thus reducing class participation (SchC-T1); many Grade 9 students echoed this, calling the topics "difficult" and "less relevant" to their daily lives (SchAS4).

Two (of five) observed Grade 9 lessons concerned China's political system and structure, and were taught by two different School C teachers (SchC-T3 and SchC-T4). SchCT3 adopted mainly an inculcation approach. She introduced China's political system and invited student groups to identify the power relationships between the National People's Congress (NPC, China's highest legislative body), State Council, Supreme People's Procuratorate, and Supreme People's Court. She guided students to conclude the NPC was the source of power for all state organs. 
SchC-T4, however, used an inquiry approach to teach the same topic. He used PowerPoint slides to outline the American and British political systems, and asked students, working in small groups, to compare them with China's and draw their own conclusions. Students were able to identify two major features of the Western political structures (the separation of executive, legislative, and judiciary powers, and the checks-and-balances function), the NPC's supremacy over China's State Council and judiciary branch, the danger of abuse of State Council power, and the importance of subsuming executive power to the NPC. At the end of students' sharing, the teacher summed up that "the three powers are separated in Western countries, but not in China" and emphasized the importance, to China, of deriving power from the Constitution and equality before the law. While reminding students it was "better not to always oppose" China's political system, SchC-T4 encouraged them "to think further about whether it is good or bad and how to improve it."

Despite their openness to diverse pedagogies, some (particularly Grade 9) teachers exercised restraint when teaching politically-sensitive topics, either by avoiding controversial or divisive issues altogether, or by denying they were controversial and helping students give expected answers (Hess, 2004). In this study, the Grade 9 topics on state policies and CPC leadership could be politically-sensitive. Grade 9 CE teachers SchA-T1 and SchC-T3 focused on the "advantages and positive sides" of contemporary Chinese politics; SchC-T3 eschewed textbook "content criticizing the CPC and its leadership," avoided mentioning the "negative side of the CPC's dictatorship," and cultivated "students' identification with Chinese politics and adherence to socialism."

To some extent, teachers' self-censorship reduced Grade 9 students' opportunities to express their viewpoints and freely discuss value-laden political issues. SchA-S4 expressed that his CE teacher taught "one-sided political knowledge and attitudes," while SchB-S12 complained there was "no need to debate on Chinese political issues" because the acceptable answer was in the textbook.

Some teachers' tendency to avoid teaching sensitive topics, and students' willingness to accept what they are taught, might reflect China's longstanding tradition of paternalism and its Confucian culture, which encourage people to be obedient, rather than question authority, for the sake of social stability and harmony (Law, 2011). However, some teachers (e.g., SchCT4) noted shortcomings in China's political system, and encourage students to evaluate it. Students had their own rational learning strategies for evaluating what they were taught.

\section{Continuing Influences of Examination Culture on Teaching and Learning}

Despite curriculum reform, public examination remains a major means of advancing students to subsequent education levels, and therefore still shapes teaching/learning, particularly of examination subjects. Persistent examination pressure is a key barrier to adopting studentcentric and inquiry-based approaches to $\mathrm{CE}$.

$\mathrm{CE}$ is a mandatory subject in the public junior secondary graduation examination (zhongkao), whose results determine admission to senior secondary schools. Although Guangzhou's CE examination is $40 \%$ closed book and $60 \%$ open book, knowledge and examination skills affect one's score more than class-learned skills and values. Students felt their $\mathrm{CE}$ teachers cared more about transmitting knowledge than skills and values, and teachers admitted being mainly concerned with whether students could answer examination questions (outcome-based teaching).

Students' examination performance can affect different stakeholders' intertwined interests, including career prospects (Law, 2014). Higher scores improve students' chances of entering a good, public senior secondary school, and save their parents from paying higher private school tuitions or illegal sponsorship fees (up to RMB50,000 per student). Additionally, local governments use public examination scores as a primary assessment criterion for schools' 
and principals' performance (SchB-T1, also School B's principal), and principals to "evaluate teachers' capability of and devotion to teaching" (SchC-T1); teachers whose students test poorly are reassigned to non-examination subjects (SchB-T4).

Accordingly, CE teachers adopted three major strategies to consolidate students' CE knowledge and improve their examination skills. First, through direct instruction, which data confirmed was the most frequently-used orientation. Second, explicitly identifying key CE textbook content for students to highlight; this was common in all observed lessons. Third, improving students' examination skills through drilling; e.g., how to read, analyze and answer questions by "following standard formats" and using CE textbook keywords.

Examination pressure could derail China's proposed pedagogical paradigm shift as, for pragmatic reasons, some students found direct instruction particularly useful. SchA-S3 (Grade 9), for example, appreciated small-group discussion's pedagogical value, but found it "time consuming" and preferred instruction that provided "right answers" to examination questions. Over-drilling could also dampen students' desire to explore CE. All interviewed Grade 9 students complained examination made CE more difficult and less interesting; SchA-S3 and SchB-S13 stated examination "emotionally agitated" them and intensified the class climate. Two interviewed teachers (SchA-T2 and SchC-T1) criticized examination for killing students' independent thinking and interests, and for forcing "passive rote learning."

\section{Conclusions}

Since 1978, Chinese society has become increasingly open and less restrictive, as reflected in CE teaching/learning at the three selected schools. This empirical study is one of the first English-medium studies to investigate the dynamics of teaching/learning Chinese CE at the classroom level and how $\mathrm{CE}$ content and pedagogies reflect societal changes. Some academics criticized Chinese CE as a means of political indoctrination (e.g., Xie \& Li, 2010); however, this study found they used the term indoctrination loosely, without clear definition or criteria, and did not provide classroom evidence to support their criticisms. The study also found far more classroom evidence in the sample schools of open pedagogies in CE than of indoctrinating pedagogies. In particular, it found no strong evidence, in terms of CE teaching intentions, content, methods or learning outcomes, satisfying Merry's (2005) criteria for indoctrination. It also found evidence supporting Grossman's (2010) view that Asian learning is not necessarily teacher-centric, but can be student-centric and inquiry-based.

This study provides empirical evidence supporting the coexistence of mixed pedagogies in the sample schools, ranging from inculcation to $\mathrm{VC}$, student-centric and inquiry-based $\mathrm{CE}$ approaches. Teachers and students followed the officially-prescribed CE curriculum and textbooks, which were intended to shape students' behaviors and values. Teachers encouraged students to accept what was taught and highlight textbook content. This can be considered inculcation (Halstead \& Taylor, 2000).

However, the CE teachers' inculcation approach was mainly for practical, not ideological, purposes, and was balanced by their promotion and implementation of inquirybased learning, which was advocated in official curriculum materials. Questionnaire and observation data revealed $\mathrm{CE}$ teachers used methods common to VC and/or enquiry-based teaching (Leming, 2010) - most commonly questioning and feedback, but also situation analysis, small-group discussion and simulation. As noted by SchA-S3 (Grade 9), the latter were time consuming and did little to help students pass knowledge-based public $\mathrm{CE}$ examinations.

Teachers acted as instructors, facilitators and guides more often than indoctrinators. In enquiry-based approaches to social and political issues, teacher-facilitators can present official views or their own to stimulate student discussion, as done in Northern Ireland (Council for the 
Curriculum Examinations and Assessment, 2014), which can be effective if competing perspectives are treated in a "balanced" manner (Hess \& McAvoy, 2015). Questionnaire and observation data showed that, while they wished students to accept what was taught, CE teachers generally presented the pros and cons of examined issues, and encouraged students to use multiple perspectives to generate their answers. They also allowed students to explain their views, albeit briefly (due to the short class period). While some teachers exercised self-restraint in teaching controversial political issues, others (e.g. SchC-T4) encouraged students to evaluate the strengths and weaknesses of China's political system.

Generally, students perceived CE classrooms as open and free, not coercive and intimidating, and felt respect, trust and acceptance were hallmarks of their CE classroom and their CE learning experiences. They openly expressed and discussed views/values from different perspectives and drew their own conclusions, did not uncritically accept knowledge contradicted by evidence, and had their own reasons and strategies for engaging in CE learning activities. CE was less accommodating in Grade 9, largely because of examination pressure and topics less relevant to students' daily lives.

These findings suggest Chinese CE teaching/learning is a contextualized socio-political exercise and practice resulting from a complex interplay among various stakeholders, and changing social teaching/learning contexts. This study has three interrelated theoretical implications for understanding teaching/learning in CE in general, and particularly in China.

The first concerns the relationship between social change and CE teaching/learning. CE teaching/learning in China is dynamic, not static, and can be shaped by social context (Graff, 2000; Tharp \& Gallimore, 1988). Changing social contexts alter manpower demands, requiring the reconstruction and recontextualization of school curricula through the reselection and reprioritization of knowledge, skills, and dispositions within or across subjects (Singh, 2002). Studies positing indoctrination in Chinese CE classrooms might have not adequately considered this or examined how China's economic and social changes have affected classroom-level CE teaching/learning.

As this study shows, Chinese authorities reformed school curricula and advocated student-centric classroom-level pedagogies in response to challenges arising from domestic reforms and international competition. CE curricula and textbook contents were accordingly reprioritized to be less ideological and more relevant to students' life spheres - familial, school, local, national and global. Reflecting China's more accommodating society, CE teachers extended their pedagogy to include strategies that encouraged thinking from multiple perspectives, supplemented textbook by providing non-traditional materials, and allowed students to express openly their views/values in small-group and class-level discussions.

Imposing a particular CE view on students is difficult in the information age and an increasingly interconnected society/world. Students can, using information technology, select and learn CE elements from diverse communities (family, school, local, national, global); school is no longer their major source of knowledge. Teachers and students in this study felt technology made indoctrination difficult, as students were constantly exposed to diverse views and perspectives.

The study's second theoretical implication concerns relationships between CE pedagogies and content. Lee (2010) associated teaching the national domain with inculcation and an emphasis on content and examination, the personal domain with reflection, and the global domain with critical thinking. However, this study found no such associations in $\mathrm{CE}$ lessons at the sample schools; rather, it found that the choice of $\mathrm{CE}$ pedagogies was not necessarily content-dependent, and that Chinese CE textbooks proposed various pedagogies for teaching/learning various $\mathrm{CE}$ domains. Teachers and students highlighted the importance of domain knowledge for examinations, and that $\mathrm{CE}$ domains intertwined during teaching/learning. Teaching the observed Grade 8 "Cooperation! Competition!" lessons, SchB- 
T3 and SchB-T4 addressed students' relationships to classmates, China and the world, and used both direct and inquiry-based instruction to engage students from multiple perspectives.

The third theoretical implication is related to the nature and function of $\mathrm{CE}$ and the roles of teachers and students. Young (1997) and Merry (2005) proposed two major elements in defining indoctrination: infringement of students' autonomous critical thinking, and their uncritical acceptance of what is taught. In this study, teachers wanted students to accept what they taught and, despite adopting both inculcation and more open pedagogies, can be seen as interfering with students' autonomy. However, this study argues that, pedagogies aside, any teacher-organized CE inevitably infringes on student autonomy in some manner, because CE is an organized socialization project preparing students to become active, responsible members (Banks, 2004) of a society with particular social/political traditions and practices (Biesta, 2009). Democratic education in Western societies is no exception (Hess \& McAvoy, 2015).

Thus, interfering with student autonomy in CE does not necessarily constitute indoctrination, and is a necessary, but not sufficient condition for the latter. Such interference could be remedied, reduced or minimized by using more open or critical pedagogies (e.g., VC or enquiry-based approaches), adopting a "balanced" approach when teaching different views (Hess, 2004), tolerating students' different opinions, and encouraging students to think from multiple perspectives and critically evaluate issues. This study found redesigned Chinese CE textbooks were made more relevant to students' daily lives and embedded inquiry-based teaching/learning by, for example, posing diverse scenarios for students to discuss. CE teachers guided students using class activity formats proposed in textbooks, including question-answer sessions and small-group discussions or activities, but also stimulated students' thinking by downloading supplemental information from other regions of China and abroad. As reflected in the survey responses, teachers guided students to evaluate issues' pros and cons in scenario analyses, and allowed them to freely express and share their views at the class level and in small-group activities. Survey and interview data showed students felt their views and their classmates' were respected.

Moreover, students can be active and rational, rather than passive, in learning CE. Students' acceptance of other CE stakeholders' (e.g., government's or teachers') views or positions is not necessarily due to inculcation or indoctrination. Such acceptance is one possible outcome when a rational choice is made, just as refuting such views is another. Although Chinese students have less learner autonomy than their Western counterparts (Halstead \& Zhu, 2009), Fairbrother (2003) demonstrated they can resist political socialization by "recognizing and evaluating the state's efforts to control this process" and exercising critical thought (p. 180). This study further revealed that, in whole-class or small-group discussions, students adopted rational $\mathrm{CE}$ learning strategies and exercised their cognitive faculty to evaluate diverse views from various sources (including government and teachers) before choosing which was better.

China's CE teaching/learning reform faces two major challenges - tension between students' active and rational learning and demands to reproduce stock answers in public examinations, and tension between CE teachers' self-censorship on politically-sensitive topics, and their encouraging students to think from multiple perspectives. These two challenges limit the autonomy and flexibility of students answering CE questions, and of teachers teaching CE topics, and are likely to intensify as China becomes increasingly globalized, its society increasingly less restrictive, and its people increasingly autonomous in their daily lives. To ease these tensions, CE assessment must be more open and aligned with students' daily experiences in school and society, authorities must be less authoritarian, and the political system more accommodating of different ideological and political perspectives.

This study has partially debunked stereotypical perceptions of Chinese CE and provided classroom evidence to support the extant literature on the increasing openness of 
Chinese CE pedagogies. However, the study is limited in its representativeness. Large-scale and/or longitudinal research on the classroom-level impact of social change and curriculum reform on Chinese $\mathrm{CE}$ teaching/learning in different geographical areas and at different educational levels is needed. As CE is affected by changing contexts, another possible direction of future research is to investigate how the tightening of political and social control under President Xi's leadership since 2013 may affect pedagogies at the classroom level. 


\section{References}

Arthur, J. (2005). The Re-Emergence of Character Education in British Education Policy. British Journal of Educational Studies, 53(3), 239-254.

Arthur, J., \& Cremin, H. (Eds.). (2012). Debates in Citizenship Education. Abingdon: Routledge.

Arthur, J., Davies, I., \& Hahn, C. (Eds.). (2008). SAGE Handbook of Education for Citizenship and Democracy. London: SAGE.

Banks, J. A. (2004). Introduction: Democratic Citizenship Education in Multicultural Societies. In J. A. Banks (Ed.), Diversity and Citizenship Education: Global Perspectives (pp. 315). San Francisco: Jossey-Bass Publishers.

Banks, J. A. (2008). Diversity, Group Identity, and Citizenship Education in a Global Age. Educational Researcher, 37(3), 129-139.

Banks, J. A. (2009). Diversity and Citizenship Education in Multicultural Nations. Multicultural Education Review, 1(1), 1-28.

Biesta, G. (2009). Good Education in an Age of Measurement: on the Need to Reconnect with the Question of Purpose in Education. Educational Assessment, Evaluation and Accountability, 21(1), 33-46.

Brady, L. (2010). Classroom-Based Practice in Values Education. In T. J. Lovat, R. Toomey, \& N. Clement (Eds.), International Research Handbook on Values Education and Student Wellbeing (pp. 211-224). Dordrecht: Springer.

Brady, L. (2011). Teacher Values and Relationship: Factors in Values Education. Australian Journal of Teacher Education, 36(2), 56-66.

Brown, M., Askew, M., Rhodes, V., Denvir, H., Ranson, E., \& Wiliam, D. (2001). Magic Bullets or Chimeras? Searching for Factors Characterising Effective Teachers and Effective Teaching in Numeracy. Paper presented at the British Educational Research Association Annual Conference, University of Leeds, Leeds.

Cantoni, D., Chen, Y., Yang, D. Y., Yuchtman, N., \& Zhang, Y. J. (2014). Curriculum and Ideology. Cambridge, MA: National Bureau of Economic Research.

Chen, Y. G., \& Reid, I. (2002). Citizenship Education in Chinese Schools: Retrospect and Prospect. Research in Education, 67(1), 58-69.

Council for the Curriculum Examinations and Assessment. (2014). Teaching Controversial Issues at Key Stage 3. Belfast: Council for the Curriculum, Examinations and Assessment.

Curriculum and Teaching Materials Research Institute (Ed.) (2009). ixiang Pinde Banianji, Shangce [Ideology and Moral Character, Grade 8, Book 1] (3rd ed.). Beijing: People's Education Press.

Curriculum and Teaching Materials Research Institute (Ed.) (2011). Sixiang Pinde Jiunianji [Ideology and Moral Character, Grade 9] (3rd ed.). Beijing: People's Education Press.

Curriculum Corporation. (2003). Values Education Study: Final Report. Carlton South, Victoria: Curriculum Corporation.

Department for Education of the United Kingdom. (2013). The National Curriculum in England: Citizenship Programmes of Study - Key Stages 3 and 4. London: Department for Education.

Dostal, J. (2015). Inquiry-based Instruction: Concept, Essence, Importance and contribution (J. Gregar \& M. Semberova, Trans.). Olomouc: Palacký University.

Fairbrother, G. P. (2003). Toward Critical Patriotism: Student Resistance to Political Education in Hong Kong and China. Hong Kong: Hong Kong University Press.

Graff, G. (2000). Teaching Politically Without Political Correctness. The Radical Teacher, 58, 26-30.

Grossman, D. L. (2010). 'Talking' about Pedagogy: Classroom Discourse and Citizenship Education. In K. J. Kennedy, W. O. Lee, \& D. L. Grossman (Eds.), Citizenship Pedagogies in Asia and the Pacific (pp. 15-33). Hong Kong: Comparative Education Research Centre, The University of Hong Kong. 
Guangzhou Education Bureau. (2002). Guangzhou Shi Jichu Jiaoyu Kecheng Gaige Shishi Yijian [Instructions on Basic Education Curriculum Reform in Guangzhou]. Guangzhou: Guangzhou Education Bureau.

Gutmann, A. (1999). Democratic Education (Second ed.). Princeton, NJ: Princeton University Press.

Halstead, J. M., \& Taylor, M. J. (2000). Learning and Teaching about Values: A Review of Recent Research. Cambridge Journal of Education, 30(2), 169-202.

Halstead, J. M., \& Zhu, C. (2009). Autonomy as an Element in Chinese Educational Reform: A Case Study of English Lessons in a Senior High School in Beijing. Asia Pacific Journal of Education, 29(4), 443-456.

Hess, D. E. (2004). Controversies about Controversial Issues in Democratic Education. PS: Political Science \& Politics, 37(2), 257-261.

Hess, D. E., \& McAvoy, P. (2015). The Political Classroom: Evidence and Ethics in Democratic Education. New York: Routledge.

Ho, W.-C. (2010). Moral Education in China's Music Education: Development and Challenges. International Journal of Music Education, 28(1), 71-87.

Holden, C. (2002). Teaching the Tricky Bits: Topical, Political and Controversial Issues. Education 3-13: International Journal of Primary, Elementary and Early Years Education, 30(2), 17-23.

Huddleston, T. (2003). Teaching about Controversial Issues: Guidance for Schools. London: Citizenship Foundation.

Huitt, W. G. (2004). Values. Educational Psychology Interactive. Retrieved from http://www.edpsycinteractive.org/topics/affect/values.html

Jackson, S. L. (2011). Research Methods: A Modular Approach (2nd ed.). Belmont, CA: Wadsworth.

Jones, A. (2002). Politics and History Curriculum Reform in Post-Mao China. International Journal of Educational Research, 37(6-7), 545-566.

Jordan, A., Carlile, O., \& Stack, A. (2008). Approaches To Learning: A Guide For Teachers: A Guide for Educators. Maidenhead, Berkshire: Open University Press.

Kennedy, K. J., Fairbrother, G. P., \& Zhao, Z. (Eds.). (2014). Citizenship Education in China: Preparing Citizens for the "Chinese Century". New York and London: Routledge.

Kennedy, K. J., Lee, W. O., \& Grossman, D. L. (Eds.). (2010). Citizenship Pedagogies in Asia and the Pacific. Hong Kong: Comparative Education Research Centre, The University of Hong Kong.

Kohlberg, L. (1978). Revisions in the Theory and Practice of Moral Development. New Directions for Child and Adolescent Development, 2, 83-87.

Law, W.-W. (2004). Globalization and Citizenship Education in Hong Kong and Taiwan. Comparative Education Review, 48(3), 253-273.

Law, W.-W. (2011). Citizenship and Citizenship Education in a Global Age: Politics, Policies, and Practices in China. New York: Peter Lang Publishing.

Law, W.-W. (2014). Understanding China's Curriculum Reform for the 21st Century. Journal of Curriculum Studies, 46(3), 332-360.

Law, W.-W., \& Ho, W.-C. (2015). Popular Music and School Music Education: Chinese Students' Preferences and Dilemmas in Shanghai, China. International Journal of Music Education, 33(3), 304-323.

Lee, W. O. (1996). Changing Ideopolitical Emphases in Moral Education in China: An Analysis of the CCP Central Committee Documents. Asia Pacific Journal of Education, $16(1), 106-121$.

Lee, W. O. (2010). Multiple Modalities of Asia-Pacific Citizenship Pedagogies: Eclectic Concepts, Hybridised Approaches and Teachers' Preferences. In K. J. Kennedy, W. O. Lee, \& D. L. Grossman (Eds.), Citizenship Pedagogies in Asia and the Pacific (pp. 335356). Hong Kong: Comparative Education Research Centre, The University of Hong Kong.

Lee, W. O., \& Ho, C. H. (2008). Citizenship Education in China: Changing Concepts, Approaches and Policies in the Changing Political, Economic and Social Context. In J. Arthur, I. Davies, \& C. Hahn (Eds.), SAGE Handbook of Education for Citizenship and Democracy (pp. 139-158). London: SAGE. 
Leming, J. S. (2010). When Research Meets Practice in Values Education: Lessons from the American Experience. In T. J. Lovat, R. Toomey, \& N. Clement (Eds.), International Research Handbook on Values Education and Student Wellbeing (pp. 91-110). Dordrecht: Springer.

Li, M. (1990). Moral Education in the People's Republic of China. Journal of Moral Education, $19(3), 159-171$.

Lickona, T., Eric, S., \& Lewis, C. (2003). CEP's Eleven Principles of Effective Character Education. Washington, D. C.: Character Education Partnership.

Lorentzen, P. L. (2013). Regularizing Rioting: Permitting Public Protest in an Authoritarian Regime. Quarterly Journal of Political Science, 8(2), 127-158.

Losito, B., \& Mintrop, H. (2001). The Teaching of Civic Education. In J. Torney-Purta, R. Lehmann, H. Oswald, \& W. Schulz (Eds.), Citizenship and Education in Twenty-Eight Countries: Civic Knowledge and Engagement at Age Fourteen (pp. 157-173). Amsterdam: International Association for the Evaluation of Educational Achievement.

Merry, M. S. (2005). Indoctrination, Moral Instruction, and Nonrational Beliefs: A Place for Autonomy? Educational Theory, 55(4), 399-420.

Ministry of Education. (2001a). Jichu Jiaoyu Kecheng Gaige Gangyao Shixing [Guidelines on the Curriculum Reform of Basic Education, Pilot]. Beijing: Ministry of Education.

Ministry of Education. (2001b). Xiaoxue Sixiang Pinde He Chuzhong Sixiang Zhengzhike Kecheng Biaozhun De Tongzhi [A Circular Concerning the Revision of the Curriculum Standards of Ideology and Moral Character in Primary Schools and Ideology and Politics in Junior Middle Schools]. Beijing: Ministry of Education.

Ministry of Education. (2001c). Yuwen Kecheng Biaozhun [Curriculum Standards for Primary Education and Junior Secondary Education: Chinese Language]. Beijing: Beijing Normal University Press.

Ministry of Education. (2012a). Yiwu Jiaoyu Sixiang Pinde Kecheng Biaozhun [Curriculum Standards for Primary Education and Junior Secondary Education: Ideological Thoughts and Moral Character]. Beijing: Beijing Normal University Press.

Ministry of Education. (2012b). Yiwu Jiaoyu Yuwen Kecheng Biaozhun [Curriculum Standards for Primary Education and Junior Secondary Education: Chinese Language]. Beijing: Beijing Normal University Press.

Ministry of Education. (2015). Zhongxiao Xuesheng Shouze [Regulations for Primary Students and Secondary Students]. Beijing: Ministry of Education.

Mintz, A. (1951). Non-adaptive Group Behavior. Journal of Abnormal and Social Psychology, $46(2), 150-159$.

Pan, S.-Y. (2011). Multileveled Citizenship and Citizenship Education: Experiences of Students in China's Beijing. Citizenship Studies, 15(2), 283-306.

Raths, L. E., Harmin, M., \& Simon, S. B. (1966). Values and Teaching. Columbus, Ohio: Charles E. Merrill.

Schulz, W., Ainley, J., Fraillon, J., Kerr, D., \& Losito, B. (2010). ICCS 2009 International Report: Civic Knowledge, Attitudes, and Engagement among Lower-secondary School Students in 38 Countries. Amsterdam: International Association for the Evaluation of Educational Achievement.

Shen, H.-1. (2009). Guanshu Lun Xueshu Lunzheng Ji Pingshu [Academic Controversies and Reviews about "Indoctrination Theory"]. Journal of Yangtze Normal University, 25(2), 134-139.

Singh, P. (2002). Pedagogising Knowledge: Bernstein's Theory of the Pedagogic Device. British Journal of Sociology of Education, 23(4), 571-582.

Superka, D. P., Johnson, P. L., Hedstrom, J. E., Ford, L. J., \& Ahrens, C. (1976). Values Education Sourcebook: Conceptual Approaches, Materials Analyses and an Annotated Bibliography. Boulder, Colo.: Social Science Education Consortium.

Tanner, M. S. (2015). Chinese Government Responses to Rising Social Unrest. Santa Monica, CA: RAND Corporation.

Taylor, M. J. (Ed.) (1994). Values Education in Europe: A Comparative Overview of a Survey of 26 Countries in 1993. Slough: National Foundation for Educational Research.

Tharp, R. G., \& Gallimore, R. (1988). Rousing Minds to Life: Teaching, Learning, and Schooling in Social Context. Cambridge: Cambridge University Press. 
Thelen, L. J. (1987). Values Clarification: Science or Nonscience. Science Education, 71(2), 201-220.

Torney-Purta, J., Lehmann, R., Oswald, H., \& Schulz, W. (2001). Citizenship and Education in Twenty-Eight Countries: Civic Knowledge and Engagement at Age Fourteen. Amsterdam: International Association for the Evaluation of Educational Achievement.

Tudball, L. (2007). Whole-School Approaches to Values Education: Models of Practice in Australian Schools. In D. N. Aspin \& J. D. Chapman (Eds.), Values Education and Lifelong Learning: Principles, Policies, Programmes (pp. 395-410). Dordrecht: Springer.

Vickers, E. (2009). Selling 'Socialism with Chinese Characteristics' 'Thought and Politics' and the Legitimisation of China's Developmental Strategy. International Journal of Educational Development, 29(5), 523-531.

Wang, X., \& Tan, C. (2014). From Ideopolitical Indoctrination to Real-Life Narration: Reform of Textbooks for Moral and Citizenship Education in China. In K. J. Kennedy, G. P. Fairbrother, \& Z. Zhao (Eds.), Citizenship Education in China: Preparing Citizens for the "Chinese Century" (pp. 195-207). New York and London: Routledge.

Xie, X., \& Li, W. (2010). Xin Zhongguo Chengli Yilai Sixiang Zhengzhi Jiaoyu De Lishi Bianqian Yu Xin De Lishi Shiming [On the Historical Changes and New Historical Mission of Ideological and Political Education since the Founding of New China]. Jiaoxue Yu Yanjiu [Teaching and Research], 5, 74-80.

Young, R. (1997). Comparative Methodology and Postmodern Relativism. International Review of Education, 43(5-6), 497-505.

Zhao, Z., \& Fairbrother, G. P. (2010). Pedagogies of Cultural Integration in Chinese Citizenship Education. In K. J. Kennedy, W. O. Lee, \& D. L. Grossman (Eds.), Citizenship Pedagogies in Asia and the Pacific (pp. 37-52). Hong Kong: Comparative Education Research Centre, The University of Hong Kong.

Zhu, X. M. (2012). Zai Jianchizhong Fazhan Yu Wanshan: Sixiang Pinde Kecheng Biaozhun Xiuding [To Persistently Develop and Improve: An Explanation for Revising the Curriculum Standard for Ideology and Moral Character]. Jichu Jiaoyu Kecheng [Basic Education Curriculum], Z1, 10-14. 